\title{
Perbandingan kualitas spermatozoa tikus wistar (rattus norvegicus) yang diberi paparan asap rokok dengan asap rokok elektronik
}

\author{
${ }^{1}$ Miseal Tooy \\ ${ }^{2}$ Lydia Tendean \\ ${ }^{2}$ Lusiana Satiawati
}

\author{
${ }^{1}$ Kandidat skripsi Fakultas KedokteranUniversitas Sam Ratulangi Manado \\ ${ }^{2}$ Bagian Biologi Fakultas Kedokteran Universitas Sam Ratulangi Manado \\ Email: tooymiseal@yahoo.com
}

\begin{abstract}
Cigarette smoke contains three main components, carbon monoxide, nicotine, and tar which can cause disturbances in spermatogenesis. Smoke electronic cigarette contains three main components, nicotine, propylene gycol, and glyceryn which can cause disturbances in spermatogenesis. The purpose of this experiment is to compare the quality of spermatozoa Wistar rats by exposure to cigarette smoke and electronic cigarette smoke. This study is an experimental study using an approach of post test only control group design. Subject of the study were 9 rats Wistar male (Rattus norvegicus) were divided into 3 groups: group $\mathrm{P}_{0}$ is not given exposure to cigarette smoke and smoke the electronic cigarette, the group $\mathrm{P}_{1}$ is given exposure to smoke cigarettes 2 rods per day, group $\mathrm{P}_{2}$ is given exposure to smoke an electronic cigarette for two rods lit cigarette. Treatment was done for 50 days. The results showed the concentration of spermatozoa is difference between the treatment groups, but statistical analysis groups $\mathrm{P}_{0}$ and $\mathrm{P}_{1}$ showed a non-significant $(\mathrm{p}=0.229), \mathrm{P}_{0}$ and $\mathrm{P}_{2}$ group $(\mathrm{p}=0.559), \mathrm{P}_{1}$ and $\mathrm{P}_{2}$ group $(\mathrm{p}=0.879)$. Motility $\mathrm{P}_{0}$ with $\mathrm{P}_{2}$ group $(\mathrm{p}=0.008)$ and group $\mathrm{P}_{1}$ and $\mathrm{P}_{2}$ group $(\mathrm{p}=0.026)$ showed significant differences which means there is a treatment effect on motility. While groups of $\mathrm{P}_{0}$ with $\mathrm{P}_{1}$ group $(\mathrm{p}=0.209)$ did not show significant differences which means there is no treatment effect on motility. Morphology Control with treatment group $1(\mathrm{p}=0.098)$ while the control group with treatment $2(\mathrm{p}=$ 0.004) it shows the morphology of the group $P_{0}$ to $P_{1}$ has no effect while the $P_{0}$ to $P_{2}$ there is an influence on the treatment.
\end{abstract}

Keywords: sperm quality, cigarette smoke, electronic cigarette smoke

\begin{abstract}
Abstrak: Asap rokok mengandung tiga komponen utama, yaitu karbonmonoksida, nikotin, dan tar yang dapat menyebabkan gangguan pada spermatogenesis. Asap rokok elektronik mengandung tiga komponen utama, yaitu nikotin, propylene gycol, dan glyceryn yang dapat menyebabkan gangguan pada spermatogenesis. Tujuan penelitin ini adalah untuk melihat perbandingan kualitas spermatozoa tikus wistar yang diberi paparan asap rokok dengan asap rokok elektronik. Penelitian ini merupakan penelitian eksperimental dengan menggunakan pendekatan post test only control group design. Subjek penelitian sebanyak 9 ekor tikus wistar jantan (Rattus norvegicus) yang dibagi menjadi 3 kelompok: kelompok $\mathrm{P}_{0}$ tidak diberikan paparan asap rokok dan asap rokok elektronik, kelompok $\mathrm{P}_{1}$ diberikan paparan asap rokok kretek 2 batang, kelompok $\mathrm{P}_{2}$ diberikan paparan asap rokok elektronik selama 2 batang rokok kretek dinyalakan. Perlakuan dilakukan selama 50 hari. Hasil penelitian menunjukkan perbedaan konsentrasi antar kelompok perlakuan namun analisa statistik kelompok $\mathrm{P}_{0}$ dan $\mathrm{P}_{1}$ menunjukkan hasil yang tidak bermakna $(\mathrm{p}=0,229)$, kelompok $\mathrm{P}_{0}$ dan $\mathrm{P}_{2}$ $(\mathrm{p}=0,559)$, dan kelompok $\mathrm{P}_{1}$ dan $\mathrm{P}_{2}(\mathrm{p}=0,879)$. Motilitas kelompok $\mathrm{P}_{0}$ dengan $\mathrm{P}_{2}(\mathrm{p}=0,008)$ dan kelompok $\mathrm{P}_{1}$ dengan kelompok $\mathrm{P}_{2}(\mathrm{p}=0,026)$ menunjukkan perbedaan bermakna yang berarti terdapat pengaruh perlakuan terhadap motilitas. Sedangkan kelompok $\mathrm{P}_{0}$ dengan kelompok $\mathrm{P}_{1}(\mathrm{p}=0,209)$ tidak menunjukkan perbedaan bermakna yang berarti tidak terdapat
\end{abstract}


pengaruh perlakuan terhadap motilitas. Morfologi kelompok Kontrol dengan Perlakuan 1 $(\mathrm{p}=0,098)$ sedangkan kelompok Kontrol dengan Perlakuan $2(\mathrm{p}=0,004)$ hal ini menunjukkan morfologi kelompok $\mathrm{P}_{0}$ dengan $\mathrm{P}_{1}$ tidak berpengaruh sedangkan kelompok $\mathrm{P}_{0}$ dengan $\mathrm{P}_{2}$ terdapat pengaruh terhadap perlakuan.

Kata kunci: asap rokok, asap rokok elektronik, kualitas spermatozoa

Peraturan Pemerintah Republik Indonesia Nomor 109 Tahun 2012 tentang Pengamanan Bahan yang Mengandung Zat Adiktif Berupa Produk Tembakau Bagi Kesehatan, rokok adalah salah satu produk tembakau yang dimaksudkan untuk dibakar dan dihisap dan/atau dihirup asapnya, termasuk rokok kretek, rokok putih, cerutu atau bentuk lainnya yang dihasilkan dari tanaman nicotonana tabacum, nicotiana rustica, dan spesies lainnya atau sintetisnya yang asapnya mengandung nikotin dan tar, dengan atau tanpa bahan tambahan. ${ }^{1}$

Asap rokok yang dihasilkan oleh perokok aktif yang kemudian dihirup oleh perokok pasif mengandung zat-zat beracun seperti nikotin, tar, dan karbonmonoksida bahkan mengandung konsentrasi zat-zat beracun dan karsinogenik yang lebih tinggi dibandingkan perokok aktif. ${ }^{2}$

Rokok elektronik terdiri dari tiga komponen utama: baterai merupakan sumber energi utama, atomizer yang menghasilkan panas pada rokok elektronik, dan tabung tempat cairan (liquid) yang mengandung berbagai macam bahan kimia antara lain mengandung nikotin cair, perasa, propylene glycol, dan glycerin atau campuran keduanya. ${ }^{2}$

Asap rokok elektronik dari hasil pemanasan mengeluarkan uap berisi nikotin yang berasal dari cairan rokok elektronik. Asap rokok mengandung berbagai zat yang tidak hanya berbahaya bagi perokok, namun juga berbahaya bagi orang lain di sekitar perokok yang menghirupnya (perokok pasif). ${ }^{3}$

Kandungan nikotin dalam bentuk cair yang dapat menempel di tubuh manusia melalui tiga cara yaitu proses inhalasi, penyerapan pada pori-pori kulit atau melalui mata, dan juga pada makanan yang terpapar asap/uap rokok elektronik. Propylene glycol dan Glycerin berfungsi sebagai alat angkut nikotin serta menciptakan uap layaknya asap rokok pada umumnya. ${ }^{4}$

WHO (World Health Organization, 2014) merilis sebuah laporan anjuran untuk tidak menggunakan rokok elektronik di dalam ruangan karena produk ini bisa mengeluarkan racun seperti rokok biasa. Meski tidak mengeluarkan asap, uap rokok elektronik mengandung zat kimia berbahaya. ${ }^{5}$ Badan Pengawasan Obat dan Makanan (BPOM, 2010) telah memperingatkan masyarakat bahwa rokok elektronik yang beredar di pasaran adalah produk ilegal dan belum terbukti keamanannya. $^{6}$

Künzle et all menyatakan bahwa merokok dapat menurunkan kualitas sperma seperti, konsentrasi, morfologi, dan motilitas sperma. ${ }^{7}$ Menurut Yeni et all, merokok juga dikaitkan dengan peningkatan kadar Reactive Oxygen Species (ROS) yang menyebabkan stres oksidatif. Stres oksidatif dapat melebihi kapasitas antioksidan yang ada dalam plasma sperma dan dapat menjadi racun dan menyebabkan kerusakan oksidatif dari sperma. $^{8}$

\section{METODE PENELITIAN}

Penelitian ini menggunakan metode penelitian eksperimentas dengan menggunakan pendekatan post test only control group design. Penelitian dilakukan di Laboratorium Biologi Fakultas Kedokteran Unsrat dengan rentang waktu penelitian 50 hari pada bulan September sampai bulan November 2016. Penelitian ini dilakukan pada Sembilan ekor tikus wistar jantan (Rattus norvegicus) berumur 12 - 14 minggu dengan berat $150-200$ gram.

Pada tahap perlakuan rokok yang sudah dibakar kemudian dimasukkan ke 
dalam lubang tempat pemberian perlakuan asap rokok. Rokok elektronik dinyalakan kemudian dihisap asapnya secara oral kemudian asap rokok elektronik dihembuskan ke tabung yang sudah dimodifikasi yang terhubung dengan kandang perlakuan paparan asap rokok elektronik. Sampel dibagi menjadi 3 kelompok, masing-masing kelompok terdiri dari 3 ekor tikus wistar. Kelompok Kontrol $\left(\mathrm{P}_{0}\right)$ tanpa paparan asap rokok dan asap rokok elektronik, kelompok perlakuan I $\left(\mathrm{P}_{1}\right)$ diberi paparan asap rokok, kelompok perlakuan II $\left(\mathrm{P}_{2}\right)$ diberi paparan asap rokok elektronik. Perlakuan asap rokok dan asap rokok elektronik ini dilakukan selama 50 hari.

Pada akhir perlakuan, hewan coba diterminasi dengan cara dilakukan dislokasi leher untuk mengambil organ reproduksi berupa kauda epididimis. Parameter yang diamati adalah konsentrasi, morfologi, dan motilitas spermatozoa.

\section{HASIL PENELITIAN}

Data yang didapatkan berasal dari 9 ekor tikus wistar berumur 12- 14 minggu dengan berat 150 - 200 gram, penelitian ini dilakukan selama 50 hari terhitung dari bulan September sampai bulan November 2016.

Tabel 1. Rerata Konsentrasi Spermatozoa Tikus Wistar (Rattus norvegicus) Setelah Pemaparan Asap Rokok

\begin{tabular}{cc}
\hline Kelompok Sampel & $\begin{array}{c}\text { Konsentrasi } \\
\text { Spermatozoa }(\mathbf{x 1 0 -} \\
\mathbf{6} / \mathbf{m L})\end{array}$ \\
\hline Kontrol & 50,1 \\
Perlakuan 1 & 63 \\
\hline
\end{tabular}

Tabel 2. Rerata Morfologi Spermatozoa Tikus Wistar (Rattus norvegicus) Setelah Pemaparan Asap Rokok

\begin{tabular}{ccc}
\hline $\begin{array}{c}\text { Kelompok } \\
\text { Sampel }\end{array}$ & $\begin{array}{c}\text { Morfologi } \\
\text { Normal } \\
(\boldsymbol{\%})\end{array}$ & $\begin{array}{c}\text { Morfologi } \\
\text { Abnormal } \\
(\boldsymbol{\%})\end{array}$ \\
\hline Kontrol & 84 & 16 \\
Perlakuan 1 & 67 & 33 \\
\hline
\end{tabular}

Tabel 3. Rerata Motilitas Spermatozoa Tikus Wistar (Rattus norvegicus) Setelah Pemaparan Asap Rokok

\begin{tabular}{ccc}
\hline $\begin{array}{c}\text { Kelompok } \\
\text { Sampel }\end{array}$ & $\begin{array}{c}\text { Motilitas } \\
\text { Normal }(\boldsymbol{\%})\end{array}$ & $\begin{array}{c}\text { Motilitas } \\
\text { Abnormal } \\
(\boldsymbol{\%})\end{array}$ \\
\hline Kontrol & 20 & 80 \\
Perlakuan 1 & 65 & 35 \\
\hline
\end{tabular}

Tabel 4. Rerata Konsentrasi Spermatozoa Tikus Wistar (Rattus norvegicus) Setelah Pemaparan Asap Rokok Elektronik

\begin{tabular}{cc}
\hline Kelompok Sampel & $\begin{array}{c}\text { Konsentrasi } \\
\text { Spermatozoa }(\mathbf{x 1 0 -} \\
\mathbf{6} / \mathbf{m L})\end{array}$ \\
\hline Kontrol & 50,1 \\
Perlakuan 2 & 60,2 \\
\hline
\end{tabular}

Tabel 5. Rerata Morfologi Spermatozoa Tikus Wistar (Rattus norvegicus) Setelah Pemaparan Asap Rokok Elektronik

\begin{tabular}{ccc}
\hline $\begin{array}{c}\text { Kelompok } \\
\text { Sampel }\end{array}$ & $\begin{array}{c}\text { Morfologi } \\
\text { Normal (\%) }\end{array}$ & $\begin{array}{c}\text { Morfologi } \\
\text { Abnormal (\%) }\end{array}$ \\
\hline Kontrol & 84 & 16 \\
Perlakuan 2 & 29 & 71 \\
\hline
\end{tabular}

Tabel 6. Rerata Motilitas Spermatozoa Tikus Wistar (Rattus norvegicus) Setelah Pemaparan Asap Rokok Elektronik

\begin{tabular}{ccc}
\hline $\begin{array}{c}\text { Kelompok } \\
\text { Sampel }\end{array}$ & $\begin{array}{c}\text { Motilitas } \\
\text { Normal (\%) }\end{array}$ & $\begin{array}{c}\text { Motilitas } \\
\text { Abnormal } \\
(\%)\end{array}$ \\
\hline Kontrol & 20 & 80 \\
Perlakuan 2 & 28 & 72 \\
\hline
\end{tabular}

Tabel 7. Rerata Konsentrasi Spermatozoa Tikus Wistar (Rattus norvegicus) Setelah Pemaparan Asap Rokok dan Asap Rokok Elektronik.

\begin{tabular}{cc}
\hline Kelompok Sampel & $\begin{array}{c}\text { Konsentrasi } \\
\text { Spermatozoa } \\
(\mathbf{x 1 0} / \mathbf{m l})\end{array}$ \\
\hline Kontrol $\left(\mathrm{P}_{0}\right)$ & 50.1 \\
Perlakuan $\left(\mathrm{P}_{1}\right)$ & 63 \\
Perlakuan $\left(\mathrm{P}_{2}\right)$ & 60.2 \\
\hline
\end{tabular}


Tabel 8. Rerata Morfologi Spermatozoa Tikus Wistar (Rattus norvegicus) Setelah Pemaparan Asap Rokok dan Asap Rokok Elektronik.

\begin{tabular}{ccc}
\hline $\begin{array}{c}\text { Kelompok } \\
\text { Sampel }\end{array}$ & $\begin{array}{c}\text { Morfologi } \\
\text { Normal (\%) }\end{array}$ & $\begin{array}{c}\text { Morfologi } \\
\text { Abnormal } \\
(\%)\end{array}$ \\
\hline Kontrol & 84 & 16 \\
Perlakuan 1 & 67 & 33 \\
Perlakuan 2 & 29 & 71 \\
\hline
\end{tabular}

Tabel 9. Rerata Motilitas Spermatozoa Tikus Wistar (Rattus norvegicus) Setelah Pemaparan Asap Rokok dan Asap Rokok Elektronik.

\begin{tabular}{ccc}
\hline $\begin{array}{c}\text { Kelompok } \\
\text { Sampel }\end{array}$ & $\begin{array}{c}\text { Motilitas } \\
\text { Normal (\%) }\end{array}$ & $\begin{array}{c}\text { Motilitas } \\
\text { Abnormal } \\
(\%)\end{array}$ \\
\hline Kontrol & 20 & 80 \\
Perlakuan 1 & 65 & 35 \\
Perlakuan 2 & 28 & 72 \\
\hline
\end{tabular}

\section{Uji Komparabilitas antar Kelompok Penelitian}

Berdasarkan hasil uji normalitas dan homogenitas, data berdistribusi normal dan homogen, maka analisis komparatif yang dilakukan adalah Uji-T Independent. Hasil analisis dapat dilihat pada Tabel 10. sampai Tabel 12

Tabel 10. Perbandingan Kualitas Spermatozoa Kelompok Kontrol $\left(\mathrm{P}_{0}\right)$ dan Perlakuan $\left(\mathrm{P}_{1}\right)$

\begin{tabular}{cccc}
\hline $\begin{array}{c}\text { Kualitas } \\
\text { Spermatozoa }\end{array}$ & $\begin{array}{c}\text { Kelompok } \\
\text { Perlakuan } \\
\left(\mathbf{P}_{\mathbf{1}}\right)\end{array}$ & $\begin{array}{c}\text { Kelompok } \\
\text { Kontrol } \\
\left(\mathbf{P}_{\mathbf{0}}\right)\end{array}$ & $\mathbf{p}$ \\
\hline Konsentrasi & 63 & 50,1 & 0,229 \\
$\begin{array}{c}\text { Motilitas } \\
\text { Normal }\end{array}$ & 65 & 20 & 0,209 \\
$\begin{array}{c}\text { Morfologi } \\
\text { Normal }\end{array}$ & 67 & 84 & 0,098
\end{tabular}

Keterangan: Nilai $\mathrm{p}<0,05$ dinyatakan memiliki pengaruh yang signifikan terhadap perlakuan.
Tabel 11. Perbandingan Kualitas Spermatozoa Kelompok Kontrol $\left(\mathrm{P}_{0}\right)$ dan Perlakuan $\left(\mathrm{P}_{2}\right)$

\begin{tabular}{cccc}
\hline $\begin{array}{c}\text { Kualitas } \\
\text { Spermatozo } \\
\mathbf{a}\end{array}$ & $\begin{array}{c}\text { Kelompo } \\
\mathbf{k} \\
\text { Perlakua } \\
\mathbf{n}\left(\mathbf{P}_{\mathbf{2}}\right)\end{array}$ & $\begin{array}{c}\text { Kelompo } \\
\text { k Kontrol } \\
\left(\mathbf{P}_{\mathbf{0}}\right)\end{array}$ & $\mathbf{p}$ \\
\hline $\begin{array}{c}\text { Konsentrasi } \\
\text { Motilitas } \\
\text { Normal }\end{array}$ & 60.2 & 50.1 & 0,559 \\
$\begin{array}{c}\text { Morfologi } \\
\text { Normal }\end{array}$ & 28 & 20 & 0,008 \\
& 29 & 84 & 0,004 \\
\hline
\end{tabular}

Tabel 12. Perbandingan Kualitas Spermatozoa Kelompok Perlakuan $\left(\mathrm{P}_{1}\right)$ dan Perlakuan $\left(\mathrm{P}_{2}\right)$

\begin{tabular}{cccc}
\hline $\begin{array}{c}\text { Kualitas } \\
\text { Spermatozoa }\end{array}$ & $\begin{array}{c}\text { Kelompok } \\
\text { Perlakuan } \\
\left(\mathbf{P}_{\mathbf{1}}\right)\end{array}$ & $\begin{array}{c}\text { Kelompok } \\
\text { Perlakuan } \\
\left(\mathbf{P}_{\mathbf{2}}\right)\end{array}$ & $\mathbf{p}$ \\
\hline Konsentrasi & 63 & 60,2 & 0,879 \\
Motilitas & 65 & 28 & 0,026 \\
$\begin{array}{c}\text { Normal } \\
\text { Morfologi } \\
\text { Normal }\end{array}$ & 67 & 29 & 0,020
\end{tabular}

\section{BAHASAN}

Hasil analisis kualitas spermatozoa yang dilakukan pada tikus wistar (Rattus norvegicus) yang dipapari asap rokok dan asap rokok elektronik menunjukan bahwa terjadi perbedaan yang bermakna dari motilitas spermatozoa dan morfologi spermatozoa tikus kelompok kontrol dan perlakuan, sedangkan konsentrasi spermatozoa tidak menunjukkan perbedaan yang bermakna dari kelompok kontrol dan kelompok perlakuan yang diberikan paparan asap rokok dan asap rokok elektronik.

Penurunanan kualitas spermatozoa yang ditemukan dalam percobaan ini disebabkan oleh pemaparan asap rokok dan asap rokok elektronik. Asap rokok mengandung berbagai zat yang tidak hanya berbahaya bagi perokok, namun juga berbahaya bagi orang lain disekitar perokok yang menghirupnya (perokok pasif). Asap rokok elektronik dari hasil pemanasan megeluarkan uap berisi nikotin yang berasal dari cairan rokok elektronik. Rokok 
elektronik menggunakan cairan yang mengandung nikotin pada konsentrasi tertentu, namun baik rokok tembakau maupun rokok elektronik sama-sama berbahaya sebab keduanya tetap mengandung nikotin. ${ }^{3}$

Radikal bebas yang ditimbulkan oleh asap rokok tidak stabil dan mempunyai reaktivitas yang tinggi. Reaktivitasnya yang tinggi ini dapat merusak seluruh tipe makromolekul seluler termasuk karbohidrat, protein, lemak, dan asam nukleat. Radikal bebas terdapat secara fisiologis pada spermatozoa manusia, namun tubuh memiliki mekanisme pertahanan endogen untuk mengimbangi radikal bebas tersebut. Pertahanan endogen ini akan memproduksi zat yang mempunyai sifat sebagai anti radikal bebas atau antioksidan, akan tetapi apabila produksi radikal bebas atau oksigen reaktif (ROS) meningkat melebihi dari sistem pertahan antioksidan tubuh maka akan menimbulkan stres oksidatif. Peningkatan dari ROS ini dapat menyebabkan terjadinya kerusakan sel, jaringan atau organ dalam tubuh. ${ }^{9-11}$

Pada kondisi stres oksidatif, radikal beabas akan menyebabkan terjadinya peroksidasi lipid membran sel dan merusak organ membran sel. Stres oksidatif dapat menyebabkan hilangnya motilitas, morfologi, dan konsentrasi spermatozoa. ${ }^{9}$

Asap rokok elektronik mengandung berbagai macam komponen yang telah teridentifikasi dalam asap rokok elektronik yaitu terdiri dari jenis bahan kimia diantaranya mengandung nikotin. ${ }^{12}$ Pemakaian nikotin secara oral berkaitan dengan terjadinya degenerasi testis dan penurunan jumlah kadar testosterone. ${ }^{13}$

Pada hasil penelitian ini dengan menggunakan uji t-independent untuk konsentrasi spermatozoa tidak menunjukkan pengaruh terhadap perlakuan baik pada kelompok Kontrol dan Perlakuan 1, kelompok Kontrol dan Perlakuan 2, kelompok Perlakuan 1 dan Perlakuan 2.

Untuk motilitas spermatozoa menunjukkan pengaruh yaitu adanya penurunan kualitas spermatozoa dalam hal ini motilitas spermatozoa pada kelompok
Kontrol dan Perlakuan 2, kelompok Perlakuan 1 dan Perlakuan 2. Dimana untuk motilitas normal spermatozoa pada kelompok Kontrol dan Perlakuan 2 memiliki nilai $\mathrm{p}=0,008$, kelompok Perlakuan 1 dan Perlakuan 2 memiliki nilai $\mathrm{p}=0,026$. Sedangkan untuk motilitas normal spermatozoa pada kelompok Kontrol dan Perlakuan 1 tidak menunjukkan pengaruh terhadap perlakuan dengan nilai $\mathrm{p}=0,209$.

Untuk morfologi spermatozoa menunjukkan adanya pengaruh yaitu adanya penurunan kualitas spermatozoa dalam hal ini morfologi spermatozoa pada kelompok Kontrol dan Perlakuan 2, kelompok Perlakuan 1 dan Perlakuan 2. Dimana untuk morfologi normal spermatozoa pada kelompok Kontrol dan Perlakuan 2 memiliki nilai $\mathrm{p}=0,004$, kelompok Perlakuan 1 dan Perlakuan 2 memiliki nilai $\mathrm{p}=0,020$. Sedangkan untuk morfologi spermatozoa kelompok Kontrol dan Perlakuan 1 tidak menunjukkan pengaruh terhadap perlakuan dengan nilai $\mathrm{p}=0,098$.

Hasil yang didapat dalam penelitian ini pada Tabel 7. terdapat rerata perbedaan konsentrasi spermatozoa dari tikus kelompok Kontrol, Perlakuan 1, dan Perlakuan 2. Dimana hasil rerata konsentrasi kelompok Perlakuan 1 (63 x $10^{6}$ spermatozoa/ml) dan Perlakuan $2(60,2$ x $10^{6}$ spermatozoa/ml) lebih banyak dibandingkan kelompok Kontrol (50,1 x $10^{6}$ spermatozoa/ml) hasil tersebut dikatakan normal. Walaupun terdapat perbedaan antar kelompok perlakuan namun hasil analisa statistik menunjukkan hasil yang tidak bermakna $(p>0,05)$ atau tidak terdapat pengaruh perlakuan terhadap konsentrasi.

Pada Tabel 8. kelompok Perlakuan 2 memiliki rerata morfologi normal spermatozoa terkecil sebesar 29\%, kelompok Perlakuan 1 memiliki rerata morfologi normal spermatozoa sebesar $67 \%$, dan kelompok kontrol memiliki rerata morfologi normal terbanyak sebesar $84 \%$. Hal ini menunjukkan penurunan/perburukan morfologi normal yang signifikan jika ditinjau dari persentase 
rerata masing-masing perlakuan. Hal ini sesuai dengan penelitian sebelumnnya yang menunjukkan bawha terjadi penurunan kualitas spermatozoa dalam hal ini morfologi normal spermatozoa pada kelompok percobaan ${ }^{2-9,10,11}$

Pada Tabel 9. terdapat perbedaan motilitas spermatozoa dari tikus kelompok Kontrol, Perlakuan 1, dan Perlakuan 2. Dimana hasil rerata motilitas normal kelompok Kontrol memiliki rerata sebanyak 20\%, kelompok Perlakuan $\left(\mathrm{P}_{1}\right)$ $65 \%$, dan kelompok Perlakuan $\left(\mathrm{P}_{2}\right) 28 \%$. Hal ini berarti pada kelompok Kontrol hanya $20 \%$ spermatozoa yang mempunyai daya tembus untuk dapat terjadi pembuahan sel telur.

Pada uji statistik perbandingan motilitas antara kelompok Kontrol $\left(\mathrm{P}_{0}\right)$ dengan Perlakuan $\left(\mathrm{P}_{1}\right)$ tidak menunjukkan perbedaan bermakna dimana $\mathrm{p}=0,209$. Sedangkan perbandingan motilitas kelompok Kontrol $\left(\mathrm{P}_{0}\right)$ dengan Perlakuan $\left(\mathrm{P}_{2}\right)$ maupun kelompok Perlakuan $\left(\mathrm{P}_{1}\right)$ dan Perlakuan $\left(\mathrm{P}_{2}\right)$ menunjukkan perbedaan bermakna $(\mathrm{p}<0,05)$ dengan nilai $\mathrm{p}=0,026$ pada perbandingan motilitas $\mathrm{P}_{1}$ dan $\mathrm{P}_{2}$ dan nilai $\mathrm{p}=0,008$ pada perbandingan motilitas $\left(\mathrm{P}_{2}\right)$ dan $\left(\mathrm{P}_{0}\right)$ yang berarti terdapat pengaruh perlakuan terhadap motilitas normal. Hal ini sesuai dengan penelitian sebelumnnya yang menunjukkan pengaruh paparan asap rokok atau asap rokok elektronik terhadap kualitas spermatozoa dalam hal ini motilitas normal spermatozoa ${ }^{2-8}$.

\section{SIMPULAN}

Berdasarkan hasil penelitian dapat disimpulkan bahwa pemberian paparan asap rokok dan paparan asap rokok elektronik berpengaruh terhadap kualitas spermatozoa tikus wistar. Terjadi perbedaan kualitas spermatozoa dalam hal ini motilitas spermatozoa dan morfologi spermatozoa dimana pada kelompok yang terpapar asap rokok lebih berpengaruh pada morfologi spermatozoa tanpa intervensi lainnya. Terjadi perbedaaan kualitas spermatozoa dalam hal ini motilitas dan morfologi spermatozoa pada dimana pada kelompok yang terpapar asap rokok elektronik lebih berpengaruh pada motilitas spermatozoa tanpa intervensi lainnya.

\section{DAFTAR PUSTAKA}

1. Peraturan Pemerintah Republik Indonesia Nomor 109 Tahun 2012 Pengamanan Bahan yang Mengandung Zat Adiktif Berupa Produk Tembakau Bagi Kesehatan. 19 November 2012. Lembaran Negara Republik Indonesia Tahun 2012 Nomor 247. Jakarta.

2. Czogala J, Goniewicz ML, Fidelus BJ, Danch WZ, Travers MJ, et al. Secondhand exposure to vapors from electronic cigarettes. Nicotine \& Tobacco Research. 2014;16:655-662.

3. Pramudiarja UAN -detikHealth. Peringatan Kemenkes: Rokok Elektrik memeberi 'Rasa Aman Semu'. 2014 March 10 [cited 22 Agustus 2016]. Available from: http://health.detik.com/read/2014/03/ 10/085338/2520519/763/peringatankemenkes-rokok-elektrik-memberirasa-aman-semu.

4. Desideria B. Ini Bahayanya Hirup Asap Rokok 'Vaping' Elektronik. 2014 Oct 31 [cited 22 Agustus 2016]. Available from:

http://health.liputan6.com/read/21271 70/ini-bahayanya-hirup-asap-rokokvaping-elektronik

5. WHO. Backgrounder on WHO report on regulation of e-cigarettes and similar products. 2014 August 26 [cited 22 Agustus 2016]. Available from: http://www.who.int/nmh/events/2014/ backgrounder-e-cigarettes/en/

6. Alianasi Masyarakat Temabakau Indonesia. BPOM Haramkan Rokok Elektrik. 2010 May 5 [Diakses 22 Agustus 2016]. Available from: http://amti.id/bpom-haramkan-rokokelektrik/

7. Künzle R, Mueller MD, Hänggi $W$, Birkhäuser MH, Drescher $\mathrm{H}$, Bersinger NA. Semen quality of male smokers and nonsmokers in infertile couples. Fertil Steril 2003;79:287-91.

8. Yeni E, Çiftçi H, Savaş M, Verit A, Taşkın A. Is oxidative stress an etiologic factor in idiopathic male infertility? Turk J Med Sci 2010;40:1-6. 
9. Karim D. Pengaruh paparan asap rokok elektrik terhadap motilitas, jumlah sperma dan kadar mda testis mencit (Mus musculus L.) [Tesis]. Medan: Universitas Sumatera Utara; 2011.

10.Aina N. Pengaruh paparan asap rokok terhadap spermatogenesis dan kualitas spermatozoa mencit (Mus musculus L.) galur Swiss [Skripsi]. Semarang: UNS; 2005.

11.Quaratul'ainy S. Pengaruh vitamin E terhadap jumlah spermatozoa mencit jantan starin balb/c yang diberi paparan asap rokok [Skripsi]. 2006.

12.Oyeyipo IP, Raji Y, Emikpe BO, Bolarinwa AF. Effects of oral administration of nicotine on organ weight, serum testosterone level and testicular pathology in adult male rats. Niger J Psychol Sci. 2010;25(1):81-86.

13.Glantz S. Nine Chemicals Identified So Far in E-Cig Vapor That Are on the California Prop 65 List of Carcinogens and Reproductive Toxins. 2013 July 20. [cited 29 Agustus 2016]. Avalaible from: http://www.tobacco.ucsf.edu/9chemicals-identified-so-far-e-cigvapor-are-california-prop-65-listcarcinogens-and-reproductive-t. 